\title{
Weapons of Mass Persuasion: Communicating Against Terrorist Ideology
}

\author{
Steven R. Corman *
}

This paper presents a communication perspective on strategies for resisting Salafist extremist ideologies such as those advocated by $\mathrm{Al}$ Qaeda and related groups. In such an effort, the first order of business is to define the audience for the ideology under consideration. Fortunately, Islamist extremists have a concept of their audience that can be estimated from statements in captured texts, on their Web sites, and so on. One estimate is shown in Figure 1. ${ }^{1}$ In general, the audience lies on a continuum stretching from the extremists themselves through various kinds of Muslims to "unbelievers" in the West.

Beginning at the extremist end of the continuum, it is well known that insiders are one target of ideological messages, and indeed extremists work hard at making sure that members of extremist groups continue to think in the "proper" ways. Thus we see elaborate religio-ideological frameworks that offer rationalizations for acts of savage violence, ${ }^{2}$ statements demonizing the enemy, ${ }^{3}$ and explicit efforts to limit the contact of members of terrorist cells with their host cultures. In large part because of such efforts, insiders are not good targets for our efforts to undermine extremist ideology. Like cult members, they are protected from external influence by a rigid system of ideological control, and no doubt are closely monitored by their colleagues. The group of outsiders is divided into "good guys" and "bad guys" (from the perspective of the extremist group members). The bad guys are indeed targets of extremist messages, but the purpose of these messages is to intimidate these adversaries and put them on notice, not to convert them to a new ideology. ${ }^{4}$ Apostates are considered lost (indeed, they are condemned) by the extremists, and the unbeliever members of other faiths are unlikely to become converts to Islam except by force.

* Steven R. Corman is a Professor in the Hugh Downs School of Human Communication at Arizona State University in Tempe, Arizona. He would like to thank Angela Trethewey for help framing the arguments in this paper, and Aaron Hess and Zachary Justus for their research assistance.

1 Steven R. Corman and Jill Schiffelbein, "Communication and Media Strategy in the Jihadi War of Ideas,” Report No. 0601, Consortium for Strategic Communication, Arizona State University (April 2006). Available at: www.asu.edu/clas/communication/about/csc/ publications/jihad_comm_media.pdf.

2 Abu Bakr Naji, The Management of Savagery, trans. William McCants, 2006; publisher unknown. Available at: www.ctc.usma.edu/naji.asp.

3 See the so-called “Al Qaeda Training Manual,” discovered by police during a raid on an Al Qaeda member's home in Manchester, U.K. in 2000. Excerpts available at www.fas.org/irp/ world/para/manualpart1_1.pdf.

4 Corman and Schiffelbein, “Communication and Media Strategy,” 12. 


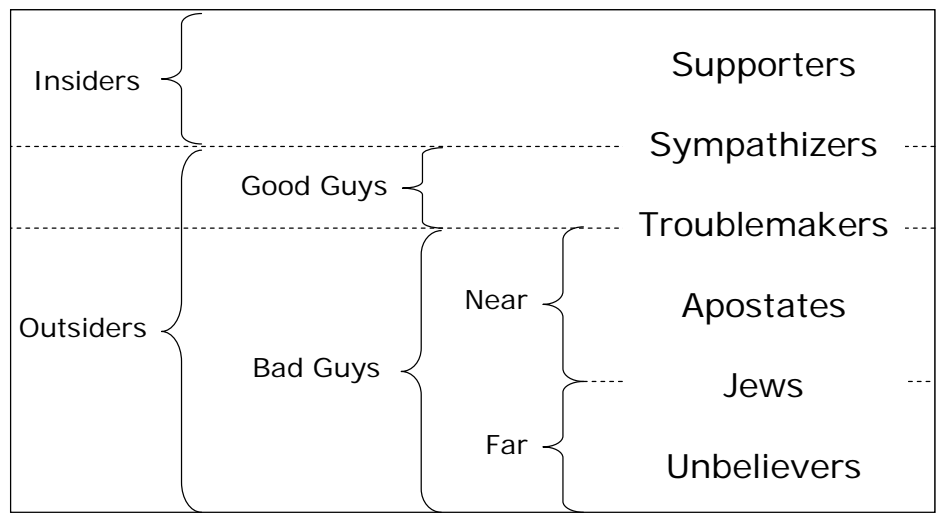

Figure 1: Jihadi Audience Concept (from Corman and Schiffelbein, 2006)

So in fact the audience for ideological influence is a rather narrow one, consisting of "good guys" who are outside the extremist movement. They range from those who already sympathize with the extremists' cause, to "good" Muslims who may have no particular association with the extremist ideology, to "troublemakers," who may have committed minor crimes but remain in the good graces of conservative Islam. These are the prime targets of extremists' attempts to offer ideological legitimization for their terrorist pursuits, and are the only people to whom it is feasible for the groups to spread their ideology. If the West is to have any success undermining extremist ideology and preventing its spread, then this must be its prime audience as well.

While this is a clearly defined audience, we must be very careful not to think of it as monolithic. This group spans almost every continent, and is divided into more than 100 religious sects. There is also a major split along lines of modernization. Indeed, many members of this potential audience for extremist Islamist ideology live in undeveloped or underdeveloped parts of the world where knowledge is strictly local. One scholar has described areas in Afghanistan where people have never traveled more than a few miles from their village, and where the inhabitants might have heard of the United States, but probably not Great Britain. ${ }^{5}$ Other members of the target audience live in major Western metropolitan centers and are subject to all the modern influences, including traditional and new media - a fact that is not lost on the extremists. ${ }^{6}$

In the face of such a diverse audience, the only hope is to focus on commonalities - the elements of the message that enable extremist ideology to spread to all the members of the "good-guy" outsiders, without the need to be customized for local conditions. Once that is done, future efforts can focus on adapting message content and

5 Rory Stewart, The Places in Between (New York: Harvest/Harcourt, 2006).

6 Jarret Brachman, “Al-Qaeda: Launching a Global Islamic Revolution” The Fletcher Forum of World Affairs (forthcoming); Corman and Schiffelbein, "Communication and Media Strategy,” 2006; Marc Lynch, “Al-Qaeda’s Media Strategies,” The National Interest 83 (June 2006). 
delivery to specific segments of the target audience. For the present purposes, then, I examine three essential components of the process that spreads extremist ideology to the potential audience: message, agent, and system. I then outline steps that the West could take against the extremists in all three areas.

\section{Message}

Definitions of ideology are as varied as they are numerous. ${ }^{7}$ The definition I use here states that ideology consists of "the taken-for-granted assumptions about reality that influence perceptions of persons and events." ${ }^{\circ}$ Under this definition, for a group to intentionally spread an ideology to some target audience, it must offer persuasive arguments that convince people to take on the group's guiding beliefs. This requirement seems particularly well suited to the culture in which Islamist extremists operate. Muslim culture is first and foremost a religious culture, and in the Salafi sect of Sunni extremists it is a decidedly ground-up affair. A Sunni religious leader does not derive authority from his position in an organizational hierarchy. Instead, he rises by building a reputation - in much the same way as a secular scholar does in the West-by making arguments and interpretations of texts that people respect, believe, find useful, and repeat to others. So authority in this brand of Islam is very much a matter of public discourse, and members of the target audience are no strangers to religious dialogue and debate.

This means that, in order for Western actors to counteract Salafi extremists' ideological influence, it must engage in argument with the extremists. In a previous paper, I have suggested that this effort include drawing attention to extremist actions that contradict the principles of Islam and offering an alternative narrative to the history of the Muslim people upon which the extremists rely. ${ }^{9}$ In this essay I argue that even more can be done by taking on the analogies that underlie extremist ideology and rhetoric.

An analogy is a form of argument that establishes in the audience's mind a similarity between two things (or reminds them of this similarity if it is already established), then says that, because the target is similar to the analogue in certain ways, we can assume it is similar to the analogue in most ways. Communicators use analogies as a means of "extending our thoughts from things we do understand to the things we do not," which is why they play such an important role in establishing the taken-forgranted assumptions of ideology. ${ }^{10}$

Perhaps the grandest of all Salafi extremist analogies compares the present situation in the Middle East to the Crusades. Abu Bakr Naji's Management of Savagery con-

7 See Willard A. Mullins, "On the Concept of Ideology in Political Science," American Political Science Review 66:2 (1972): 498-510.

8 Stanley Deetz and Astrid Kersten, “Critical Modes of Interpretive Research,” in Organizational Communication: An Interpretive Approach, Linda Putnam and Michael Pakanowshy, eds. (Beverly Hills, CA: Sage, 1983), 162.

9 Corman and Schiffelbein, "Communication and Media Strategy."

10 A. Juthe, “Argument by Analogy,” Argumentation 19:1 (2005): 3. 
tains extensive passages on the "lessons learned" from the Crusades. ${ }^{11}$ For example, he argues that in Islamic history there are "critical periods when a caliphate falls and another is established, or during our exposure to foreign attacks, like the Tartar and Crusader attacks." ${ }^{12}$ He uses the Crusades analogy to defend the organizational structure used by present-day Salafi groups. In doing so, he criticizes those who misunderstand the analogy and

ignorantly think that this part of Islamic history dealing with the Crusaders was accomplished by the state uniting to command the Muslims. This is a clear mistake. The readers who carefully examine this time period see that the Muslims dealt with the matter of the Crusaders by means of small bands (tajammu 'ät saghìra) and separate, disparate organizations. ${ }^{13}$

In other words, the historical situation is analogous to the present one and, because small bands defeated the old Crusaders, small bands can defeat the new Crusaders too.

This analogy is so important that it is regularly re-injected into Islamist discourse. In February 2006, Osama bin Laden said:

It is a war which is repeating (bringing back) the Crusades, similarly to the previous wars. Richard [the] Lion Heart, and Barbarossa from Germany, and Louis from France... similarly is the case today, when they all immediately went forward the day Bush lifted the cross. The Crusader nations went forward. What is the concern of the Arab nations in this Crusaders' War? They entered it openly, without disguise, in broad daylight [safaaran, jahaaran, nahaaran]. They have accepted to be ruled by the cross. ${ }^{14}$

Later, bin Laden explicitly drew on this analogy to frame Al Qaeda's work as a small part of the worldwide struggle between Islam and the West, as if to make his own efforts further evidence for the analogy: "Alhamdulillah... I say that the battle isn't between the al-Qai'dah Organization [tanzeem al-Qai'dah] and the world Crusaders. The battle is between Muslims - the people of Islam — and the world Crusaders." 15

Another popular extremist analogy compares the present situation in Iraq to the defeat of Soviet forces in Afghanistan. A person identified as "alss7ab," posting on "Usama’s Memo Forum” in January 2005, also predicted that defeat in Iraq

entails catastrophic consequences for the American Empire and its allied rulers in our Islamic world. United-States witnessed the disintegration and collapse of the SovietUnion following the latter's defeat and withdrawal from Afghanistan. Without achieving victory or expanding its influence, the Soviet-Union conceded defeat in the

11 Naji, Management of Savagery, 2006.

12 Ibid., 12.

13 Ibid.

14 Osama bin Laden, “A Discussion on the New Crusader Wars,” interview by Tayseer Allouni (21 October 2001), translated by Muawiya Ibn Abi Sufyan. Available at www.terrorisme.net/ doc/qaida/001_ubl_interview_a.htm.

Ibid. 
war of attrition that almost depleted its resources. Two years later, the former SovietUnion ceased to exist. ${ }^{16}$

Bin Laden, in the speech quoted above, said that, just as Allah helped Muslim fighters defeat the Soviets, He would help them defeat the Americans too.

These are only two examples, but Salafi extremist texts contain many analogies. This is no doubt in part because kiyas, or argument by analogy to scripture, is a wellestablished tradition in Islamic philosophy, and is thus a form of argumentation with which the target audience would be familiar. ${ }^{17}$ Even more important, analogies involve the audience in the persuasive process, making them powerful tools in the work of converting ideas into taken-for-granted assumptions. Once audience members accept the analogy's basic comparison, they fill in gaps in their knowledge about the target by drawing on their knowledge of the source. The audience more or less persuades itself, establishing conditions of concertive control. ${ }^{18}$ This self-persuasion is not just an outcome but a process that can continue long after exposure to the message, as new "unknowns" about the target are recognized. Second, because they are based on a structure of comparisons between the analogue and target, analogies are difficult to disrupt. Simple counterexamples, which are standard tactics against other kinds of arguments, are nearly irrelevant to analogies because it is similarity, not dissimilarity, that matters. $^{19}$

It is possible to argue against analogies, but the choice of strategies is not straightforward. Shelley proposes a useful scheme that is based on two strategic questions: Is the basic comparison underlying the analogy valid or not? and, Is the objective to dissolve the analogy and leave nothing in its place, or to replace it with something else? ${ }^{20}$ Answers to these questions yield four different strategies for arguing against the analogies, summarized in Table 1. For each strategy, the table gives an abstract version of the preferred argument and the prescribed method for making it.

Answering even these two simple questions is surprisingly difficult and complex. It is safe to say that Western governments (especially the United States under the present administration) would resist endorsing any beliefs or arguments of Islamist extremists, especially their key analogies. But in that case, half of the possible strategies for deal ing with the analogies are taken off the table. The remaining two strategies depend

16 Alss7ab, "The Emancipation of Mankind and Nations Under the Banner of the Koran," Usama's Memo Forum (accessed 30 January 2005). This web forum is no longer in existence.

17 A.M. Maghraoui, ”American Foreign Policy and Islamic Renewal,” Special Report 164, United States Institute of Peace (2006). Available at: www.usip.org/pubs/specialreports/ sr164.html.

18 Philip Tompkins and George Cheney, “Communication and Unobtrusive Control in Contemporary Organizations, in Organizational Communication: Traditional Themes and New Directions, Robert McPhee and Philip Tompkins, eds. (Thousand Oaks, CA: Sage, 1985).

19 Juthe, “Argument by Analogy,” 2004.

20 Cameron Shelley, “Analogy Counterarguments: A Taxonomy for Critical Thinking,” Argumentation 18 (2004): 223-38. 
THE QUARTERLY JOURNAL

Table 1: Analogy Counterarguments (adapted from Shelley, 2004)

\begin{tabular}{|c|c|c|c|c|}
\hline Analogy is & \multicolumn{2}{|c|}{ Invalid } & \multicolumn{2}{|c|}{ Valid } \\
\hline Goal is to & Dissolve & Replace & Dissolve & Replace \\
\hline Strategy & False Analogy & Misanalogy & Disanalogy & Counteranalogy \\
\hline $\begin{array}{l}\text { Counter- } \\
\text { argument }\end{array}$ & $\begin{array}{l}\text { The analogy seems } \\
\text { correct on the sur- } \\
\text { face, but falls apart } \\
\text { on further exami- } \\
\text { nation }\end{array}$ & $\begin{array}{l}\text { The analogy is } \\
\text { wrong, and } \\
\text { there is a dif- } \\
\text { ferent one that } \\
\text { is right }\end{array}$ & $\begin{array}{l}\text { The analogy } \\
\text { seems to be true, } \\
\text { yet the facts do } \\
\text { not obey its } \\
\text { structure }\end{array}$ & $\begin{array}{l}\text { The analogy } \\
\text { seems to be true, } \\
\text { but there is a } \\
\text { better analogy for } \\
\text { explaining the } \\
\text { same situation }\end{array}$ \\
\hline Objective & $\begin{array}{l}\text { Make the audience } \\
\text { to struggle to map } \\
\text { things that aren't } \\
\text { similar }\end{array}$ & $\begin{array}{l}\text { Create a new, } \\
\text { more coherent } \\
\text { analogy with a } \\
\text { conclusion that } \\
\text { undermines the } \\
\text { original one }\end{array}$ & $\begin{array}{l}\text { Identify charac- } \\
\text { teristics that the } \\
\text { analogue and } \\
\text { target should } \\
\text { share, but don't }\end{array}$ & $\begin{array}{l}\text { Use a different } \\
\text { analogue to make } \\
\text { a claim about the } \\
\text { target that is in- } \\
\text { compatible with } \\
\text { the original claim }\end{array}$ \\
\hline
\end{tabular}

on the ability to make convincing arguments about the flaws in the analogy, and one of them also requires a well-argued alternative. Given the low credibility of the United States and other Western nations in the Muslim world at present, it would be an uphill battle to make such arguments succeed. ${ }^{21}$ Admitting the validity of some of the extremists' points might offer the chance to "hijack" their arguments, but if the effort were unsuccessful it could backfire and strengthen their position. Also complicating the picture is the fact that strategies seeking to replace the original analogy require an alternative that is a better analogy: If the present situation is not like the Crusades or the Soviet occupation of Afghanistan, then what is it like? If there is no convincing answer to that question, then efforts to disrupt the analogies are further constrained.

To sum up this brief look at analogy, it is an important aspect of Salafi extremist messages, and it is a unique form of argument that cannot be refuted using conventional methods. The extremists know the power of this technique to frame the thinking of their audience and control them, so they regularly use analogies in their discourse. To interfere with the spread of their ideology, it is important to argue against these analogies, yet we cannot answer some of the basic strategic questions that would guide our response, and we lack systematic research into possibilities for countering them. Moreover, our own ideology may place constraints on our strategies for doing so. Ex-

21 Steven R. Corman, Aaron Hess, and Zachary S. Justus, "Credibility in the Global War on Terrorism: Strategic Principles and Research Agenda,” Report No. 0603, Consortium for Strategic Communication, Arizona State University (June 2006). Available at: www.asu.edu/ clas/communication/about/csc/documents/csc_credibility_gwot.pdf. 
panding knowledge about extremist analogies and clarifying our own limitations in this area are keys to successful resistance efforts.

\section{Agent}

The message aspects of counter-ideology communication are important, but we must also recognize that ideologies have consequences because of the actions of individuals. When people adopt an ideology and start viewing the world through its lens, they become its agents. This is crucial because, without human agents to sustain and promote them, ideologies either die or lie dormant in texts.

Ideologies are spread through communicative processes, and disseminating them involves persuading people who are not believers to take up the cause. What incentives do members of the target audience have to adopt a Salafi extremist ideology? For some time, experts believed that terrorists are recruited from the ranks of those who are poor, desperate, unemployed, alienated, and/or sociopathic. ${ }^{22}$ While some undoubtedly fit this profile, subsequent research has shown that other terrorist recruits are educated, economically comfortable people who have opportunities and a chance for a normal life, but take up the extremist cause anyway. ${ }^{23}$

A communication-based explanation that accommodates both of these cases is based on the concepts of identity and identification. An identity is a set of concepts that a person uses as a resource for creating a sense of self-a notion of "being somebody"-while identification is the act of drawing on these resources to project an image of the self to others. ${ }^{24}$ For example, a profession is an identity many people have that influences how they interact with people. It is common for one's profession to come up in interactions, even with strangers. Knowing someone's profession allows us to fill in many blanks about them (and for them to assume that we have, in fact, filled them in), so it facilitates effective communication. ${ }^{25}$

Adopting extremist ideology functions in much the same way; it provides a resource that the adopter can use to "be somebody." A good illustration of this is the case of exiled Syrian dissident Ammar Abdulhamid. The son of famous and well-to-do parents in Syria, Abdulhamid decided as a teenager to become a radical Muslim fundamentalist. In a recent interview, here is what he had to say about his conversion:

22 Anne Speckhard, "Understanding Suicide Terrorism: Countering Human Bombs and Their Senders," in Topics in Terrorism: Toward a Transatlantic Consensus on the Nature of the Threat, Vol. 1, Jason S. Purcell and Joshua D. Weintraub, eds. (Washington, D.C.: Atlantic Council Publications, 2005).

23 Robert A. Pape, Dying to Win: The Strategic Logic of Suicide Terrorism (New York: Random House, 2005).

24 Craig R. Scott, Steven R. Corman, and George E. Cheney, “Development of a Structurational Model of Identification in the Organization,” Communication Theory 8:3 (1998): 298-336.

25 Sarah J. Tracy and Angela Trethewey, "Fracturing the Real-Self $\leftarrow \rightarrow$ Fake-Self Dichotomy: Moving Toward 'Crystallized' Organizational Discourses and Identities,” Communication Theory 15:2 (2005): 168-95. 
Interviewer: "Earlier in your life, when you were in college, you had become a fundamentalist Muslim, and from what I've read even considered going to Afghanistan in the late '80s to fight the Soviets. How did you become a radical Muslim?"

Abdulhamid: "Well this is one of those things that I've never really understood myself, completely. However, it seems the reasons were far more psychological than ideological. I was a very introverted child, and I had my mom's fame and my father's fame, and sort of being under the spotlight all the time was not very comfortable for me. It brought the envy and jealousy of my peers in school, and I really never was comfortable with it. So I guess what happened is, at one point religion empowered me. Instead of saying 'I'm shy,' I can always say 'I'm religious. I'm not introverted, I'm just not interested in going out and drinking and following girls.' I wanted to, but I was simply too shy and inadequate. So I covered my teenage inadequacies with a layer of religiosity. And at the same time religion really managed to bring me out of my shell because a lot of the instruction is to actually go out and go to Mosques, and to meet with people, and to pray, and to be active. So Islamic fundamentalism actually slowly made me break my shyness, made me become more social, stand up on my own two feet, and interact with people with much more confidence" [emphasis added.$^{26}$

In other words, Abdulhamid's fundamentalist identity facilitated effective communication about who he was. This is not an isolated case. Nada Farooq, a member of a recently broken terrorist cell in Toronto and whose first name is pronounced "Needa," was called "Needa Shower" in high school by her classmates. She grew to hate Canada, everyone there, and Western culture in general. ${ }^{27}$ There are parallels in the cases of the Jabarah brothers, also in Canada, as well as in those of John Walker Lindh and Adam Gadahn in the United States. Early evidence indicates that some of the U.K. liquid bombers apprehended in the summer of 2006 are what we might call "identity converts" (though we do not know how they were treated in school) ${ }^{28}$ For Muslims with an intense need to be somebody, believe something, and prove things to the worldwhatever the source of those needs - extremist ideology offers a very attractive package. The fact that it comes with the added legitimacy of being wrapped in religion is only a bonus.

This is not to argue that the ideology is justified, but that people who adopt it are motivated to do so. Althusser stated that ideology spreads through a "hailing" function, where individuals and institutions involved in promoting an ideology call on susceptible motivated individuals to accept the taken-for-granted assumptions that constitute

${ }^{26}$ Ammar Abdulhamid, Syrian dissident, interview by Terri Gross, "Fresh Air," National Public Radio (U.S.), broadcast 1 August 2006. Available at: www.npr.org/templates/story/ story.php?storyId $=5597594$.

27 Omar el Akkad and Greg McArthur, "Hateful Chatter Behind The Veil," Ottawa Globe and Mail (6 July 2006).

28 "Papers Pore over 'Bomb Plot,”' BBC Online (11 August 2006). Available at: http://news.bbc.co.uk/2/hi/uk_news/4782397.stm. 
it. ${ }^{29}$ If people are called to extremism, it is not enough to offer them an alternative of something that is simply "not-jihad." There must be a competing ideology that calls the individual more strongly. Indeed, we know that hailing by competing ideologies is a worry to the extremists. It is worth noting here that ideologies are rarely completely consistent or "totalizing" in their effects. Even the most radical and seemingly impenetrable ideologies may contain a variety of internal contradictions, tensions, and ruptures. These ideological ruptures may provide opportunities for Western counter-ideological efforts to highlight and exploit wedge issues within radical ideologies. ${ }^{30}$ For instance, Osama bin Laden has complained about the risk of potential young radicals being siphoned off by more peaceful clerics: "Most unfortunately, the young people who have the ability to sacrifice for the religion are suffering by listening to and obeying Islamic clerics who refrain [from violence], even though such people must not be listened to or obeyed.",31

Defining a competing identity for would-be extremists is beyond the scope of this paper, and doing so is fraught with political complications. Some would undoubtedly complain that such an effort smacks of a liberal social engineering project. But if the goal is to be proactive in resisting Salafi extremist ideology, it is difficult to see any alternative to promoting some competing targets of identification or exploiting the various contradictions that exist in radical ideologies-however that might be accomplished. As long as there is a vacuum of unfulfilled needs that it can meet, extremist ideology will continue to seep in and convert a certain percentage of the Muslim population that is motivated to accept its calling.

\section{System}

Ideologies operate within social systems, and what happens in these systems has as much to do with the sustainability of any ideological project as the message or people who spread it. Yet public discourse about terrorism often ignores this fact, treating the terrorists as the only party to the conflict that has an ideology. For example, in a recent speech, United States President George Bush said: "We face an enemy that has an ideology; they believe things. The best way to describe their ideology is to relate to you the fact that they think the opposite of the way we think."32

It would have been more accurate for Mr. Bush to say, "Salafi ideology is the opposite of Western ideology.” Indeed, Salafi extremist discourse regularly draws upon

29 Louis Althusser, "Ideology and Ideological State Apparatuses," in Literary Theory: An Anthology, J. Rivkin and M. Ryan, eds. (Malden, MA: Blackwell, 1998).

30 Angela Trethewey and Karen L. Ashcraft, "Practicing Disorganization: The Development of Applied Perspectives on Living With Tension," Journal of Applied Communication Research 32 (2004): 81-88.

31 Speech by Osama bin Laden, “Directions Regarding Methodology_Part One,” Clear Guidance, date unknown (late 1990s).

32 George W. Bush, Remarks by the President at Bob Corker for Senate and Tennessee Republican Party Dinner, Loews Vanderbilt Hotel, Nashville, TN (30 August 2006). Available at: www.whitehouse.gov/news/releases/2006/08/20060830-7.html. 
ideological tenets of the West in justifying itself and defining its positions. Thus, when the United States publicly professes a goal of bringing democracy to the Middle East through the war in Iraq, the extremists capitalize on this claim, preaching that democracy is a form of polytheism that is against Islam: "So, the democracy is on one side a polytheism and on the other side a disbelief in Allah that contradicts with monotheism, the religion of the Messengers, and Prophets, for many reasons." 33 When the United States paints the Al Qaeda attack on the World Trade Center as a barbaric attack on innocent people, Osama bin Laden responds:

In the case we kill their civilians, the whole world yells at us from east to west, and America would start pushing its allies and puppets. Who is the one that said that our blood isn't blood and their blood is blood? Who is the one that declared this? What about the people that have been killed in our lands for decades? More than 1,000,000 children died in Iraq and are still dying, so why don't we hear people that cry or protest or anyone who reassures or anyone who gives condolences??!? ${ }^{34}$

There are many other such examples. Extremist authors regularly draw on incidents in Guantanamo Bay and Abu Ghraib to argue that the West is an oppressive force bent on committing atrocities against Muslims. The presence of Western forces in the Arabian Peninsula is used to strengthen their Crusades analogy, which was described above. "There's no question the war in Iraq is radicalizing the people in that area," says 9/11 Commissioner Tom Kean. ${ }^{35}$ The recent partially declassified National Intelligence Estimate concludes that, "the Iraq conflict has become the 'cause celebre' for jihadists, breeding a deep resentment of U.S. involvement in the Muslim world and cultivating supporters for the global jihadist movement."36

Recently the West has presented the extremists with another strategic communication bonanza, the 2006 conflict between Israel and Hezbollah in Southern Lebanon. The United States' staunch support for Israel and perceived foot-dragging on diplomatic efforts to halt the fighting gave the jihadis fresh evidence to press claims about the wicked "Zionist-Crusader Alliance" that is seeking to dominate the Muslim world. "Azzam the American," the adopted name of Adam Gadahn, an alleged American-born member of Al Qaeda who has served as a spokesman to Western media for the organization, recently said

To what can we attribute the obvious ignorance of Western peoples in general toward the religion of the Muslims and its teachings? This ignorance, which causes the peo-

33 Abu Muhammad al-Maqdisi, Democracy: A Religion!, trans. Abu Muhammad al-Maleki and Abu Sayf Muwahhid (At-Tibyaan Publications, n.d.). Bin Laden, "Discussion on the New Crusader Wars."

$A B C$ This Week (10 September 2006). Available at: http://abcnews.go.com/ThisWeek/ story?id=2416319\&page=3.

Director of National Intelligence, Declassified Key Judgments of the National Intelligence Estimate Trends in Global Terrorism: Implications for the United States (Washington, D.C.: April 2006). Available at: http://www.dni.gov/press_releases/Declassified_NIE_Key_ Judgments.pdf.

Alss7ab, 2005. 
ple of the West to rapturously applaud when Israel perpetrates wholesale slaughter of Muslims in Lebanon and Palestine, and leads them to give their assent to the atrocities their governments commit in Afghanistan, Iraq, and elsewhere in the Muslim world, and makes them voice their approval when their armies desecrate copies of the Koran in Guantanamo and televangelists insult our Prophet Muhammad, peace be upon Him. These events, coupled with these reactions, showcase a seething animosity and definite ignorance of the religion of Islam and the nature of its followers.... Today, the televangelists, false prophets, and charlatans prey on the gullible, and the illiterate are glorying in Israel's blood lust and excessive appetite for destruction in Lebanon and Palestine. ${ }^{38}$

In example after example, Salafi extremist discourse is buttressed by actions of the West that are attributable to Western ideology. This highlights three related challenges facing any effort to resist the appeal of these extremist ideologies. First, we believe in our ideology in the same way that the jihadis believe in theirs. Nobody in the West is going to abandon their belief in democracy just because some extremist says it amounts to polytheism. Second, our ideology constrains the choices we are able to make in other aspects of our efforts against the jihadis. I have already noted that we may selflimit our options for resisting their key analogies. It is likewise unclear whether we would, for example, promote the study of Islam under radical clerics in order to compete with the jihadis for recruits. Third, as in the Southern Lebanon situation, our efforts to resist jihadi ideology are often constrained or compromised by other policy considerations.

There are several responses that would help Western nations face these challenges. One is to change our own identification practices, to reduce the "footprint" of our ideology in the region. The more strongly we reproduce Western ideals within the discourse of terrorism, the more opportunities we create for Salafi extremists to reproduce their viewpoint. The West would do well to change the subject from the goals of Western action in the Middle East, and instead focus on the extremists' ideology and its contradictions and limitations. With regard to its own image, the West should rely more on principles of strategic ambiguity, and less on classical principles of control. ${ }^{39}$

A second response is to decide whether we are willing to alter our thinking or policy in exchange for more ideological leverage against the jihadis. If not, then we should accept the fact that there may not be much we can do (beyond keeping a low profile) to affect the ideological discourse, assume it will continue to convert a certain percentage of the target audience, and concentrate on other ways of dealing with the jihadi challenge. But if we are serious about changing the ideological equation, there are some

38 Azzam the American, “Invitation to Islam,” As-Sahab Productions (2 September 2006). Available at: www.lauramansfield.com/j/zawahiri090106.asp.

39

Bud Goodall, Angela Trethewey, and Kelly McDonald, "Strategic Ambiguity, Communication, and Public Diplomacy in an Uncertain World: Principles and Practices,” Report No. 0604, Consortium for Strategic Communication, Arizona State University (June 2006). Available at: www.asu.edu/clas/communication/about/csc/documents/StrategicAmbiguityCommunication.pdf. 
relatively modest changes in position and policy that could help significantly. For example, we might grant some of the jihadi analogies in order to open up the associated options for counterargument.

A third potential response is to take more seriously the risk of providing support for jihadi ideology when making policy decisions. There is disregard (if not outright denial) of the positive impact of our own policy decisions on the spread of jihadi ideology. Thus these effects-which clearly do exist-are essentially unintended consequences of our policy making, as the above examples show. To seriously take these effects into account, they should be made explicit in our policy decisions. We should include a variable like "probability of supporting jihadi ideology" in our risk calculations for policy decisions.

\section{Conclusion}

The audience for the spread of Salafi extremist ideology is a relatively small population of fairly observant co-religionists in the Muslim world who are outside the extremist circle. Any Western effort to resist the spread of these ideologies must focus on this population and deal with problems of message, agent, and system. Message-related efforts should focus not only on contradictions in jihadi ideology, but also on the key analogies they use to create concertive control in their audience. Doing this requires systematic research on their ideological rhetoric and careful consideration of the options for making counterarguments.

Agent-related efforts must take account of the fact that Islamist extremism is an identity that provides people a resource for projecting an image of an effective self to the outside world. In short, it is a way of "being somebody" that apparently exerts a powerful call to Muslims from a broad range of social circumstances. Because the movement is meeting basic needs for social inclusion, an alternative of "not-jihadism" is insufficient. Alternative targets of identification must be made available and promoted, or else extremists will continue to attract converts from their target audience.

System-related efforts must come to terms with jihadis' use of Western beliefs and actions as a resource for reproducing their own ideology. In the current environment, the West shoots itself in the foot whenever it makes its beliefs or actions prominent in the conversation in the target audience. A reduced public discourse footprint and the practice of strategic ambiguity can help lessen this effect. Going farther, modest changes in position and policy_like granting the validity of some extremist arguments or including ideology risk in policy calculations_could also deny jihadis some of their most important ideological weapons. 


\section{Bibliography}

Corman, Steven R., and Jill Schiffelbein. Communication and Media Strategy in the Jihadi War of Ideas. Consortium for Strategic Communication, Arizona State University, 2006.

Deetz, Stanley, and Astrid Kersten. "Critical Modes of Interpretive Research." In Organizational Communication: An Interpretive Approach. Beverly Hills, CA: Sage, 1983.

Juthe, A.. "Argument by Analogy." Argumentation 19, no. 1 (2005).

Lynch, Marc. "Al-Qaeda's Media Strategies." The National Interest 83 (2006).

Mullins, Willard A.. "On the Concept of Ideology in Political Science." American Political Science Review 66, no. 2 (1972): 498-510.

Shelley, Cameron. "Analogy Counterarguments: A Taxonomy for Critical Thinking." Argumentation 18 (2004).

Stewart, Rory. The Places in Between. New York: Harvest/Harcourt, 2006.

Tompkins, Philip, and George Cheney. "Communication and Unobtrusive Control in Contemporary Organizations." In Organizational Communication: Traditional Themes and New Directions. Thousand Oaks, CA: Sage, 1985. 